\title{
Smartphone Addiction/ Overuse and Its Effect on Dietary Behavior and Lifestyle -A Systematic Review
}

Ayesha Manzoor ${ }^{1}$, Rabia Basri ${ }^{2}$, Iraj Ali ${ }^{3}$, Saman Javaid ${ }^{4}$, Maha Amjad ${ }^{5}$, Urooj Amin ${ }^{6}$, Hafsa Kamran ${ }^{7 *}$

${ }^{1-6}$ Student, University Institute of Diet and Nutritional Sciences, the University of Lahore, Punjab, Pakistan

${ }^{7}$ Assistant Professor, University Institute of Diet and Nutritional Sciences, Faculty of Allied Health Sciences, the University of Lahore (UOL), Pakistan

Article History
Received: 12.08 .2020
Accepted: 03.09 .2020
Published: 21.10 .2020

Journal homepage:

https://www.easpublisher.com/easjnfs

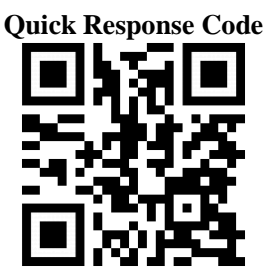

Abstract: Smartphones have progressively been turned out to be the most important segment of our lives because of their several advantages but in recent modern years, the negative consequences of smartphone useage has also been raised. Intention to write this review was to summarize the evidences that have illustrated a significant influence of smartphone addiction/overuse on the dietary behavior and lifestyle of university/college/school students. Research was conducted in accordance with the principles of systematic review. Four databases were searched and found total 62 studies, and only 12 relevant observational, open access studies were extracted that included participants with smartphone addiction/overuse, and its effect on dietary behaviors, the sleep habits and physical activity or exercise pattern. All the studies stated negative correlation between smartphone addiction/overuse and dietary behavior, sleep pattern and physical activity. Investigations of all the included studies stated that, due to excessive use of smartphones, students had poor eating behavior, and were more likely to develop nutritional deficiencies and might suffer from health consequences and psychopathologies. Students wo had smartphone addiction adopted a sedentary lifestyle, and were more prone to suffer from physical fitness and might develop non-communicable diseases like CVD and obesity in future. In all studies researchers suggested the common intervention that effective nutrition education and awareness programs must be initiated to bring students toward healthy lifestyle.

Keywords: Smartphone addiction, smartphone overuse, dietary behavior, lifestyle, sleep disorders, physical activity.

Copyright (C) 2020 The Author(s): This is an open-access article distributed under the terms of the Creative Commons Attribution 4.0 International License (CC BY-NC 4.0) which permits unrestricted use, distribution, and reproduction in any medium for non-commercial use provided the original author and source are credited.

\section{INTRODUCTION}

Addiction, by WHO (WHO Expert Committee - 1964) is thought to be the dependence, as the continuous use of something for the sake of relief, comfort, or stimulation, which often causes cravings when it is absent [1, 2, 3]. Two main classes of addiction that includes either substance addiction, e.g. "drugs or alcohol addiction" or "behavioral addiction such as mobile phone addiction" [4].

The smartphone is described as a mobile phone that executes most of the tasks of a processor. It usually has a touch screen, access to Internet, and an effective working system that is proficient of proceeding downloaded applications [3]. A Smartphone is a term for differentiating cell phones, with improved characteristics from fundamental phones' characteristics. The term "Smartphone" originally emerged in 1997, when Ericsson explained its GS 88 "Penelope" idea/notion as a smartphone [5]. Smartphones have progressively been turned out to be the most important/key segment of our lives because of their several advantages, for example, comfortability to access news, data and evidence, an easy social connectivity, work station applications, comfort, easy to move, small size, and so on. Furthermore, now a days, smartphones are working very crucially and significantly in the health care departments, as health care professionals and patients both pursue to encourage effective health or health care facilities for the patients. However, in recent modern years, the negative consequences of smartphone useage have also been raised [6].

Smartphone addiction has been founded upon the description of Internet addiction, "smartphone addiction has been described as "the excessive use of smartphones to such a degree/level, that it interrupts the routine life of a user. Furthermore, an excessive use of mobile phone may bring about mental or behavioral issues. It may result in behavioral issues, affect or delay school or routine work performance, lessen or diminish real-life social communication, negligence in personal 
life, mental preoccupation, mood adapting experiences and can cause relationship disorders as well [7]."

Smartphone addiction/abuse/misuse is the most uncontrollable and excited kind of "mobile phone" use by students, worldwide. Among students, "smartphone's addiction/abuse/misuse" is a novel sort of health disorder and now it is compelling the health policy creators to think on this rapidly arising issue all around the world [8]. Before smartphones usage become more prevalent, a study in Saudi Arabia connected mobile phones usage to various health hazards, including sleep disturbances (4.\%), tension (3.9\%), fatigue (3\%), and dizziness (2.4\%) [9]. Afterward, findings of another research in Saudi Arabia revealed that $44.4 \%$ of subjects (medical students) were recognized of headaches, reduced attention, memory loss, hearing loss, and lethargy due to excessive use of smartphones [10].

The smartphone usage rate was $62 \%$ that was discovered to be the highest among the age group of 2534 , all around the world. Worldwide, $50 \%$ and $43 \%$ of Android and Apple devices users were younger than 34 years of age. Among them, $47 \%$ of Smartphone users are female while $53 \%$ are male. Recently, Indian adolescents have been operating/running Smartphone's market place in India. The percentage of 16-18 years of adolescents using Smartphone increased from 5\% -25\% in 2012 to early 2014. In 2013, "51 million" Smartphone users were discovered in Urban India and the percentage was increased to $90 \%$ in the year of 2013 than 2012 [8].

More and more adolescents like to explore their smartphones or use it for their amusement in their spare time, for this reason smartphone's exploitation is increasing in the $21^{\text {st }}$ Century. Excessive smartphone use may be an indication of Smartphone addiction [4, 11]. Latest research investigations in US recommends that extreme use of mobile phone, has intensified the danger of critical psychological disorders in adolescents. Furthermore, there is an expanding proof of problematic Smartphone's usage that has a significant influence on both social and health phases of users' lives [11, 12]. Findings of another study in Korea also revealed that those adolescents, who have extreme Smartphone's usage, had considerably more critical psychopathologies, including problematical behaviors, somatic signs, ADHD, and aggression [12].

The investigations of a study in Cheongju illustrate that $52 \%$ of bad sleep standards were related to excessive smartphone usage [13]. In Saudi Arabia, university students are at danger of smartphone addiction. $27.2 \%$ of the subjects use their cell phones for $>8$ hours each day. As an after-effect of using the smartphones, minimum of $43 \%$ subjects have reduced sleeping hours, and suffer from deficient energy levels the next day, $30 \%$ used to eat fast food, had sedentary lifestyle and gain more weight; In fact they had more unhealthy lifestyle, while academic performance had been being harmfully influenced of $25 \%$ of students [14].

Findings of studies on Korean university students illustrated that students were extremely reliant on smartphones. Students used to skip breakfast more frequently and had an irregular eating pattern and unfavorable food choices (e.g. eating processed food, over eating and skipping meal in diet). Among highusage group. When evaluating the eating behavior, the students who had reduced time spent on smartphone usage were found to eat with regularity and punctuality with healthy food choices [15]. In $6^{\text {th }}$ grade Korean schoolchildren, students who overuse smartphone and spend more than 2 hours per day have paid more money for snack foods, preferably ice cream, junk food, and fizzy drinks [16].

Researchers, all over the world, gathered students' point of view about smartphone addiction and found that it help students to hide from academic load. Moreover, students use smartphone apps for their academic work. Accessibility of low rate packages of internet, instant messages and calls are important reasons of youth attraction towards smartphones in Pakistan. The results regarding Smartphone usage and family income had showed adverse indications [17]. The highlights of this study include latest scientific facts and research analysis of the smartphones addiction on human health and life. Smartphone addiction can be defined as "individuals spending most of their time in scrolling, watching, liking, commenting, stalking and talking to their friends through different mobile applications [18]".

A report of Korea Communications Commission showed that the smartphone users have been approximated to be more than twenty million. According to Statistics Korea, almost forty million people own smartphones that shows the outspread of this smart device [19]. A survey was conducted by Stanford University, found that students confessing it would be "a tragedy" to lose their phone and $22 \%$ saying that it is "dangerously alluring," the ratio still show the addictive power of smartphones [20]. A study was conducted in South Korea to examine smartphone use patterns, smartphone addiction characteristics, and the predictive factors of the smartphone addiction in middle school students that show $30.9 \%$ people are at risk of smartphone addiction [21].

Relationships among smartphone addiction, communication ability, loneliness, \& interpersonal relationships were investigated in university students in Korea. The results explained $36.6 \%$ of the total variance. In order to improve university students' human relationship health, solutions for smartphone addiction and low communication skills are required. Results of this study can 
be used as a basis on which develop a human relationship health intervention program [22]. Physical activity and its relationship with smartphone addiction were studied in Chinese international students in Korea. Excessive usage of smartphones may induce social problems, such as depression and impairment of social \& emotional functioning and impede physical activity [23].

Correlation between smartphone addiction and eating behaviors cannot be ignored. A study was conducted in the Ansan area. Rate of reducing physical activity and sleep disorders and skipping meals due to using a smartphone were high in the addiction group as compared to the normal group [24]. In order to know a relationship of anxiety and depression among students with and without smartphone addiction a study was conducted in South Punjab Pakistan. The results showed that smartphone addiction significantly positively correlated with, depression, anxiety and stress [25]. Prevalence rates of smartphone related compulsive behaviour, functional deterioration, mental attitude and withdrawal evidence were evidentiary among a sample of Lebanese university students. $35.9 \%$ felt fatigue during daytime due to late-night smartphone use, $38.1 \%$ declared decreased sleep quality, and $35.8 \%$ slept less than four hours due to smartphone usage [26].

\section{Material ANd Methods}

Quality of studies was assessed using JBI appraisal check list for analytical cross-sectional studies and only high-quality studies were included.

\section{EVIDENCE EQUISITION \\ Research Strategy}

The search was conducted according to the principles of Systematic Reviews. The searched databases were: PubMed (2012-2020), google scholar (2013-2020), science direct (2015-2020), and Scopus. The key terms searched were smartphone addiction, problematic smartphone use, smartphone overuse and dietary behaviors. Terms must include: smartphone addiction with diet or dietary habits. Terms may include: lifestyle, sleep pattern, sleep disorders, exercise, physical activity, BMI and smoking. Using these key terms, researchers found total 62 studies from the above-mentioned data bases. Among these researchers found 41 studies from google scholars, 14 from science direct and 7 from PubMed. Researchers found no studies from Scopus. After this, researchers separated the relevant and irrelevant data, while 12 relevant and open access studies were extracted/shortlisted, from the searched data (Fig.1).

\section{Inclusion / Exclusion Criteria and Study Design Selection}

The selection criteria included those studies that included participants with smartphone addiction/ overuse, and its effect on dietary behaviors, the sleep habits and physical activity or exercise pattern. All relevant observational (cross-sectional) studies were included. All irrelevant studies to our research tittle, randomized control/clinical trials (RCTs), and nonmatched retrospective $\&$ prospective studies and chart reviews were excluded.

\section{Types of participants}

The participants of our study were all apparently healthy students of both gender between the age of 12-30 years.

\section{Types of outcome measures Dietary behavior}

Numerous studies have been performed to investigate the association/link between smartphone addictions \& dietary patterns among school/college/university students. A study conducted by Sun-Hee Lim et al. in 2016 [15], among the university Korean students, intention of the research was to explore the dietary behavior, lifestyle, food \& beverages consumption pattern, and smartphones' usage among 550 students of university. It was an observational cross-sectional study and data was collected via survey using questionnaires. Finally, 520 subjects were classified in three different groups depending upon their smartphone usage duration per day: first group was categorized as less-users who use cell phones less than 4.7 hours, second group was of intermediate-users who use more than or equal to 4.7 hours but less than 6.4 hours, and third group was of extreme-users group who use more than or equal to 6.4 hours of their smartphones each day. Findings of studies on Korean university students illustrated that students were extremely reliant on smartphones. Students used to skip breakfast more frequently and had an irregular eating pattern and unfavorable food choices (e.g. eating processed food, over eating and skipping meal in diet). Among high-usage group. When evaluating the eating behavior, the students who had reduced time spent on smartphone usage were found to eat with regularity and punctuality with healthy food choices [15].

While in 2017, a similar study was conducted by Kyung-Ae Park among the University Students of Korea with almost the same purpose to examine nutritional and lifestyle behavior, eating habits and food frequency depending upon the extent of smartphone addiction among 408 students of university in Kyungnam state. With the help Smartphone Addiction Poneness Scale (SAPS), researchers assessed that $28.4 \%$ were at danger of developing smartphone addiction while $13.2 \%$ were smartphone addicted. Smartphone addicted students have high percentage of smartphone usage at meal and snack times. Slow eating speed, taste changes, limiting salty food, excessive drinking, oils/nuts \& fatty meat consumption and frequent meal skipping was more prevalent in smartphone addicted students as compared to normal users [27]. Therefore, in both studies researchers suggested the common intervention that there is an extreme urge to initiate effective nutrition awareness 
programs to solve unhealthy dietary and lifestyle habits from high-risk smartphone users in university students[15, 27].

In 2020, another study was conducted by Kyoung Min Kim et al. [28]. The intention of this study was to examine the relationship between specific food consumption and the duration or time of smartphone, and the consequences of smartphone overuse in adolescents. In this study, both food ingestion and their cell phone usage, routines were observed in Korean adolescents. Results of this study indicated that, $66.5 \%$ of adolescents use smartphones greater than 2 hours daily. Higher consumption rates of healthier foods, such as, fruits, vegetables and milk were shown in reduced smartphone users. Whereas, elevated rates of consuming unhealthy foods including, fizzy drinks, sugary beverages, junk food, noodles, \& snacks, were found among adolescents who use their mobile phones excessively soda, energy drinks, sweetened beverages, fast food, instant noodles, and snacks was linked with higher smartphone use [28]. Therefore, to cope-up with this problem, nutrition education intervention program has become necessary to maintain a healthy lifestyle of our future generations.

Along with the university students, Smartphone addiction has become an increasing trend among school going children as well. A study was conducted by Eun Ji Kim and Seong Young Kim in 2015 [24], examined the association of smartphone addiction with eating patterns of addicted and normal students. The study participants were 288 school students of 5th and 6th class in the Ansan region. Among 288 students $29(10.1 \%)$ were addicted and 259 students $(89.9 \%)$ don't have addiction. Smartphone addicted group has elevated smartphone usage time as compared to normal group. There was a high percentage of using a smartphone during meal times and meal skipping due to excessive smartphone usage. So, the duration of using cell phones was boosted while healthy eating habits were reduced with increased cell phone usage time during the weekends and the frequency of snack consumption was increased among smartphone addicted students as well [24].

While, 2 years later another study was conducted by So Hee Han et al. in 2017 [29], with the same objectives and participants to the previous study. Participants were 286 students of elementary school (fifth and sixth grade) in Siheung and Ansan areas. The investigations of this study illustrated almost the same results as the previous study revealed, that the smartphone addicted students had considerably elevated duration of using cell phones as compared to normal students during the weekdays \& weekends as well. Dietary approaches and eating pattern showed that most of the students are more prone to skipping meals, changing eating speed, and changing meal amount due to excessive smartphone usage [17].
Meanwhile another study was conducted by Hayeon Kim and Munkyong Pae in 2017, to investigate the duration of using mobile phones and its relation with eating pattern, lifestyle, and nutrition awareness among 372 (5th \& 6th grade) school students, in Cheongju, Korea. Results of this research illustrated, about half of the students $(41.4 \%)$ use smartphones for $\geq 2$ hours/day. $63.4 \%$ of students like to have snacks during the time of watching TV, operating PC or a cell phone while $48.1 \%$ consumed snacks when they just use a smartphone and food preference was ice cream, junk food, \& fizzy drinks. Both conditions were more predominant among those excessive users of cell phones ( $\geq 2$ hours/day). Therefore, in the above discussed studies, author suggested the same intervention that educational programs must be initiated to bring awareness and guarantee healthy eating behaviors among smartphone addicted students [16].

\section{Sleep pattern}

Smartphone addiction is significantly affecting students' lifestyle. Particularly sleep pattern among university students. Findings of a study conducted by Po-Yu Wang et al. in 2019 [30], illustrated that sleep quality was considerably linked to extent of mobile phone exposure. The lower the participants' extent/level of smartphone exposure, the improved their sleep quality was [30]. In another study conducted by Yasemin P. Demir and Mehmet M. Sümer in 2019, similar results were found. Results of this study illustrates that Smartphone overuse has been examined to poor sleep quality and daytime sleepiness. Moreover, increase/elevation in the smartphone usage, provoke daytime sleepiness, reduces the sleep quality, and quality of life is reduced as well [31].

Furthermore, Mobile phones play an essential role in adolescents' life. A study performed by Christoph Randler et al. 2016 [32] illustrated significant investigations that morningness-eveningness is a vital interpreter of mobile phone overuse or addiction. Evening oriented students showed elevated scores on both smartphone addiction scales and females were more likely to be addicted. In addition, sleep duration showed negative results on SAPS during the weekdays [32]. While findings of another research performed by Ruchi Soni et al. in 2017 [2] states that due to increased acceptance of smart phones, youth spend more time on their cell phones and acquire addictive propensity. In addiction investigations of this study not only states that youth are only addicted to smartphones but they develop considerable behavior and sleep difficulties/disorders as well due to overuse use of smart phones[2].

\section{Physical Activity}

With the advancement of technology, smartphone usage has been increased, in recent years, and physical activity has been reduced. This reduction 
in physical activity has become an essential risk factor for non-communicable diseases, particularly CVD and metabolic diseases. Numerous studies were conducted, to examine the influence of cell phone overuse addiction on the physical activity of students. A study conducted by Andrew Lepp in 2013 stated there is a negative and considerable association between smartphone cardiac and respiratory health regardless of gender, self-efficacy, and presence of fat (an important indicator). The high frequency users were more susceptible to sacrifice the chances for physical activity for the purpose of using their cell phones and develop sedentary/inactive behaviors. In contrast to this, limited mobile phone users were more susceptible of being attached to their active peers via mobilephones and refer this as an inspiration for physical activity. So, overuse of mobile phones elevates sedentary lifestyle among students [33]. A similar study conducted by Sung-Eun Kim et al. 2015 investigations stated that smartphone addiction has adverse consequences on physical health as it has reduced the extent of physical activity. Reduction in walking can raise the intensity of fat mass $\&$ reduction in muscle mass, causing health hazards [23].

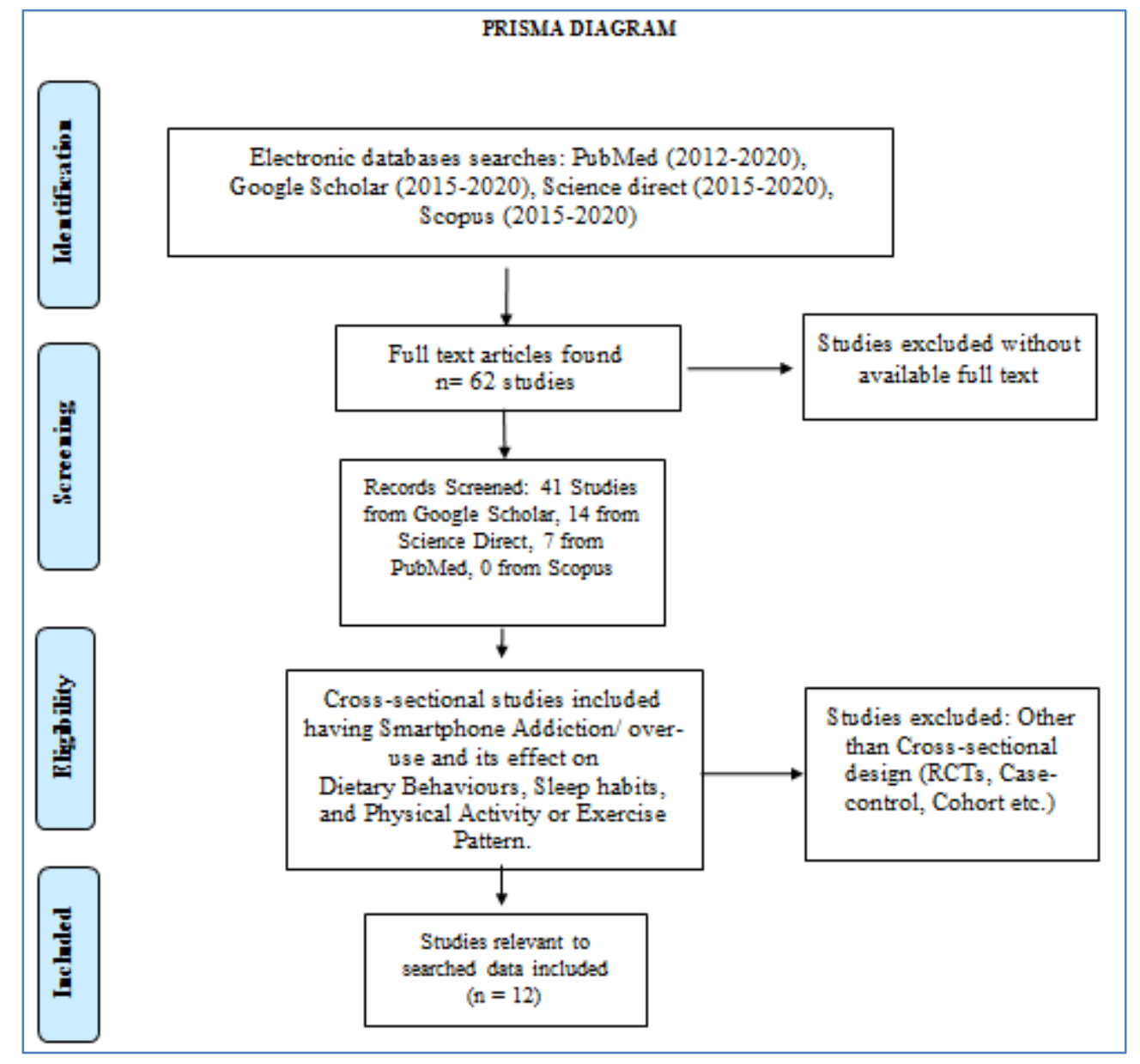

\section{DISCUSSION}

The study was conducted to assess the extent of smartphone use and their effect on the dietary patterns among university students, within 5 years span, in accordance with principles of systemic review. The results of various studies are discussed and comparisons are made where necessary. The purpose of the study, conducted by Sun-Hee Lim et al. in 2016 on Korean university students was to investigate the dietary status, lifestyles, eating habits and smartphones' usage. Both genders of apparently healthy university students were found to be smartphone addicts. The addiction touched their lives from their dietary patterns to physical strength. The participants who have reduced smart device usage, were assessed to eat more regularly and at fixed times than those with high smart device users, who were assessed to overeat and consume processed foods more often. The results suggested that limiting mobile phone usage will show favorable results [15].

Another study done in 2017 by kyung-Ae Park among the university students to examine their nutritional and standard living habits, eating behaviors and food regularity in conferring with The Smartphone Addiction Proneness Scale. It evaluated potential-risk and high-risk smartphone users. In high risk and potential-risk groups, the levels of depression, stress and frequency of snacks were higher than in the normal group. Percentages of using a smartphone, at meal time, while snacking were also higher in these groups. The comparative study of these groups revealed that an 
effective nutrition education was needed to resolve unhealthy dietary and lifestyle habits for their healthy future [27].

A study done recently in 2020 by kyoung Min et al. has also revealed the association between smartphone usage time and consumption of specific foods in adolescents. Higher consumption rates of healthier foods, such as, fruits, vegetables and milk were shown in reduced smartphone users, whereas, elevated rates of consuming unhealthy foods including, fizzy drinks, sugary beverages, junk food, noodles, \& snacks, were found among adolescents who use their mobile phones excessively. Nutrition education intervention has become the necessity of the time. Because not only the university students but the school going children have also become the addicts of the smart devices (tabs, laptops etc.) [28, 23].

The smartphone use has also affected students' health by disturbing their sleep cycle. Jing-wen He et al. conducted a study in 2020 to investigate the impact of inhibiting smartphone usage before going to bed, it improves the sleep length, enhances sleep quality, decreases pre-sleep arousal, enhance memory. Their hours of sleep have reduced because of the smartphone use. Not only the time but the use has also affected their quality of sleep. The quality of sleep is also affecting the youths' behavior and health in their daily lives. Christopher Randler et al. showed another important predictor than sleep duration i.e. morningnesseveningness. Higher scores on both smartphone addiction scales were shown by evening oriented students. These studies concluded that the smartphone addiction is affecting students' lives by developing significant sleep and behavior problems [30-32].

Another factor touched by the smartphone use is the physical activity of the youth. Due to the use of smartphones, the risk of reduced physical strength has increased because of reduced physical activity leading to increased risk of non-communicable diseases, particularly CVD and metabolic diseases. The findings of the studies conducted by Andrew Lepp 2013 and a similar study done in 2015 by Sung-Eun Kim et al. respectively revealed that quality of physical activity, including a little walk, decreases in high-risk and dangerous-risk smartphone users. Another predictor of the addiction is the gender i.e. girls are more addicts than boys. Ruchi Soni et al. in 2017 stated that youths spend significant amount of their times using smartphones with its increasing popularity [33, 24].

\begin{tabular}{|c|c|c|c|c|c|}
\hline \multirow{2}{*}{$\begin{array}{l}\text { Author, } \\
\text { Year \& } \\
\text { Location } \\
\end{array}$} & \multirow{2}{*}{$\begin{array}{l}\text { Study Design } \\
\text { \& Sample } \\
\text { Size }\end{array}$} & \multirow[t]{2}{*}{$\begin{array}{l}\text { Participants } \\
\text { of studies }\end{array}$} & \multicolumn{3}{|c|}{$\begin{array}{l}\text { Results } \\
\text { Influence of Smartphone addiction/overuse on }\end{array}$} \\
\hline & & & Dietary behavior & sleep pattern & $\begin{array}{l}\text { physical activity/ } \\
\text { Exercise Pattern }\end{array}$ \\
\hline $\begin{array}{l}\text { Sun-Hee } \\
\text { Lim et al. } \\
2016 \\
\text { Korea }\end{array}$ & $\begin{array}{l}\text { Cross- } \\
\text { sectional/ } \\
\text { observational } \\
\text { (survey based) } \\
\text { study } \\
520\end{array}$ & $\begin{array}{l}\text { University } \\
\text { students }\end{array}$ & $\begin{array}{l}\text { Students using high } \\
\text { frequency of smartphone } \\
\text { (more than } 6.4 \text { hours) per } \\
\text { day, are found with frequent } \\
\text { skipped meals, particularly } \\
\text { breakfast, with irregular } \\
\text { eating habits. Consume } \\
\text { more processed food and } \\
\text { overeat. }\end{array}$ & & \\
\hline $\begin{array}{l}\text { Kyung-Ae } \\
\text { Park; } \\
2017 \\
\text { Kyungnam } \\
\text { province }\end{array}$ & $\begin{array}{l}\text { Cross- } \\
\text { sectional/ } \\
\text { observational } \\
\text { (survey based) } \\
\text { study } \\
408\end{array}$ & $\begin{array}{l}\text { University } \\
\text { students }\end{array}$ & $\begin{array}{l}\text { Use more smart-phone at } \\
\text { meal or snack time. } \\
\text { Skipping meals \& slow } \\
\text { eating speed, avoiding salty } \\
\text { foods, eating oils or nuts, } \\
\text { fatty foods and excessive } \\
\text { drinking behavior was found } \\
\text { among high and potential } \\
\text { risk users. }\end{array}$ & & \\
\hline $\begin{array}{l}\text { Kyoung } \\
\text { Min Kim } \\
\text { et al } \\
2020 \\
\text { Korea }\end{array}$ & $\begin{array}{l}\text { Cross } \\
\text { sectional study } \\
\text { (survey } \\
\text { based). } \\
62,276\end{array}$ & $\begin{array}{l}\text { Korean } \\
\text { adolescent } \\
\text { students }\end{array}$ & $\begin{array}{l}\text { Due to higher smartphone } \\
\text { usage, higher consump-tion } \\
\text { of fizzy drinks, sugary } \\
\text { beverages, junk food, } \\
\text { noodles, \& snacks, was } \\
\text { found among adolescents }\end{array}$ & & \\
\hline $\begin{array}{l}\text { Eun Ji } \\
\text { Kim \& } \\
\text { Seong } \\
\text { Young } \\
\text { Kim 2015 } \\
\text { Ansan }\end{array}$ & $\begin{array}{l}\text { Cross } \\
\text { sectional study } \\
\text { (survey based) } \\
288\end{array}$ & $\begin{array}{l}\text { Elementary } \\
\text { school } \\
\text { students }\left(5^{\text {th }}\right. \\
\left.\& 6^{\text {th }} \text { grade }\right)\end{array}$ & $\begin{array}{l}\text { Meal skipping and using } \\
\text { smartphone during eating } \\
\text { was increased. Good eating } \\
\text { habits decreased with } \\
\text { increased usage time during } \\
\text { the weekends while snack }\end{array}$ & & \\
\hline
\end{tabular}




\begin{tabular}{|c|c|c|c|c|c|}
\hline area & & & $\begin{array}{l}\text { intake frequency was } \\
\text { increased during the } \\
\text { weekdays among smart- } \\
\text { phone addicted students. }\end{array}$ & & \\
\hline $\begin{array}{l}\text { So Hee } \\
\text { Han } \text { et al. } \\
2017 \\
\text { Siheung } \\
\text { and Ansan } \\
\text { areas }\end{array}$ & $\begin{array}{l}\text { Cross } \\
\text { sectional study } \\
\text { (survey based) } \\
286\end{array}$ & $\begin{array}{l}\text { Elementary } \\
\text { school } \\
\text { students }\left(5^{\text {th }}\right. \\
\left.\& 6^{\text {th }} \text { grade }\right)\end{array}$ & $\begin{array}{l}\text { Meal skipping, eating speed } \\
\text { changes, changing meal } \\
\text { amount due to increased } \\
\text { smartphone usage. }\end{array}$ & & \\
\hline $\begin{array}{l}\text { Hayeon } \\
\text { Kim \& } \\
\text { Munkyong } \\
\text { Pae } \\
2017 \\
\text { Cheongju; } \\
\text { Korea }\end{array}$ & $\begin{array}{l}\text { Cross } \\
\text { sectional study } \\
\text { (survey based) } \\
372\end{array}$ & $\begin{array}{l}\text { Elementary } \\
\text { school } \\
\text { students }\left(5^{\text {th }}\right. \\
\left.\& 6^{\text {th }} \text { grade }\right)\end{array}$ & $\begin{array}{l}63.4 \% \text { of students like to } \\
\text { have snacks during the time } \\
\text { of watching TV, operating } \\
\text { PC or a cell phone while } \\
48.1 \% \text { consumed snacks } \\
\text { when they just use a } \\
\text { smartphone and food } \\
\text { preference was ice cream, } \\
\text { junk food, \& fizzy drinks. }\end{array}$ & & \\
\hline $\begin{array}{l}\text { Po-Yu } \\
\text { Wang } e t \\
\text { al. } \\
2019 \\
\text { Southern } \\
\text { Taiwan }\end{array}$ & $\begin{array}{l}\text { Cross } \\
\text { sectional study } \\
409\end{array}$ & $\begin{array}{l}\text { College } \\
\text { students }\end{array}$ & & $\begin{array}{l}\text { Reduction in smartphone } \\
\text { overuse can improve the } \\
\text { quality of sleep. }\end{array}$ & \\
\hline $\begin{array}{l}\text { Yasemin } \\
\text { P. Demir } \\
\text { and } \\
\text { Mehmet } \\
\text { M. Sümer } \\
\text { in } 2019 \\
\text { Neurology } \\
\text { clinic } \\
\text { Turkey }\end{array}$ & $\begin{array}{l}\text { Cross } \\
\text { sectional } \\
\text { comparative } \\
\text { study. } \\
123\end{array}$ & $\begin{array}{l}\text { Migraine } \\
\text { patients }\end{array}$ & - & $\begin{array}{l}\text { An increased } \\
\text { smartphone usage } \\
\text { caused decrease in sleep } \\
\text { and cause more } \\
\text { sleepiness at daytime, } \\
\text { reducing the quality of } \\
\text { life. }\end{array}$ & - \\
\hline $\begin{array}{l}\text { Christoph } \\
\text { Randler et } \\
\text { al. } \\
2016 \\
\text { Germany }\end{array}$ & $\begin{array}{l}\text { Cross } \\
\text { sectional study } \\
342\end{array}$ & $\begin{array}{l}\text { Younger } \\
\text { adolescents }\end{array}$ & - & $\begin{array}{l}\text { morningness- } \\
\text { eveningness, an } \\
\text { important and stronger } \\
\text { predictor of smartphone } \\
\text { usage rather than sleep } \\
\text { duration. sleep duration } \\
\text { on weekdays negatively } \\
\text { predicted SAPS. }\end{array}$ & - \\
\hline $\begin{array}{l}\text { Ruchi } \\
\text { Soni et al. } \\
2017 \\
\text { India }\end{array}$ & $\begin{array}{l}\text { Cross } \\
\text { sectional study } \\
587\end{array}$ & $\begin{array}{l}\text { School } \\
\text { students } \\
\text { (adolescents) }\end{array}$ & - & $\begin{array}{l}\text { Youth develop } \\
\text { significant sleep and } \\
\text { behavior problem due to } \\
\text { excessive smartphone } \\
\text { usage. }\end{array}$ & - \\
\hline $\begin{array}{l}\text { Andrew } \\
\text { Lepp } \\
2013 \\
\text { US }\end{array}$ & $\begin{array}{l}\text { Cross } \\
\text { sectional study } \\
\text { (interview }+ \\
\text { survey based) } \\
\text { Random } \\
\text { sampling }\end{array}$ & $\begin{array}{l}\text { US college } \\
\text { students }\end{array}$ & - & - & $\begin{array}{l}\text { Smartphone usage } \\
\text { negatively affect cardio } \\
\text { fitness. Increased usage } \\
\text { reduced chances of } \\
\text { physical activity and } \\
\text { leads to a sedentary } \\
\text { lifestyle, causing heart } \\
\text { problems (CVDs). }\end{array}$ \\
\hline $\begin{array}{l}\text { Sung-Eun } \\
\text { Kim et al. } \\
2015 \\
\text { Korea }\end{array}$ & $\begin{array}{l}\text { Cross- } \\
\text { sectional study } \\
\text { (survey based) } \\
\text { SAPS were } \\
\text { used. } \\
110\end{array}$ & $\begin{array}{l}\text { Chinese } \\
\text { international } \\
\text { students in } \\
\text { korea }\end{array}$ & - & - & $\begin{array}{l}\text { Smartphone addiction } \\
\text { has reduced the extent } \\
\text { of physical activity. } \\
\text { Reduction in walking } \\
\text { can raise the intensity } \\
\text { of fat mass \& reduction } \\
\text { in muscle mass, and } \\
\text { ultimately lead to health }\end{array}$ \\
\hline
\end{tabular}




\begin{tabular}{|l|l|l|l|l|l|}
\hline & & & & consequences \\
\hline
\end{tabular}

\section{CONSLUSION}

Smartphone addicted or overuse students were found to have more disturbed eating patterns, skipped meals and consume unhealthy food choices like consumption of fizzy drinks, sugary beverages, junk food, noodles, fatty and jink foods were higher. Poor sleep quality and reduced sleeping hours were more prevalent among excessive smartphone usage group. Smartphone addiction/overuse has reduced the extent of physical activity. Reduction in walking can raise the intensity of fat mass \& reduction in muscle mass, causing health hazards (e.g. non-communicable diseases like obesity, CVD, cancer etc.). Therefore, effective nutrition education and awareness programs must be initiated to improve the quality of life and bring students toward healthy lifestyle.

\section{ACKNOWLEDMENT}

All gratitude towards the Allah Almighty who is most gracious \& merciful, without whose help nothing is possible.

Ayesha Manzoor, pays a special thanks to her brothers; M. Rashid Manzoor, M. Usman Manzoor, \& her Mother, for being her backbone \& eternal strength, and also for their assistance, motivation, \& courage in this project.

Many thanks to our most respectable Miss Hafsa Kamran (the supervisor of this project), for providing her precious time, guidance \& appreciation throughout the project.

\section{REFERENCES}

1. Khan, F., \& Aniyan, A. T. (2019). A Descriptive Study to Assess the Level of Smartphone Addiction and Quality of Sleep among Student Nurses in Selected College of Nursing, New Delhi. International Journal of Nursing \& Midwifery Research (E-ISSN: 2455-9318), 6(1), 710.

2. Soni, R, U. R. (2017). International Journal of Research in Medical Sciences. ;5(2):515-9.

3. LP, I. S. B. (2014). Before IPhone and Android Came Simon, the First Smartphone. Bloomberg Businessweek. [Last updated on 2012 June 30.

4. Kim, H. (2013). Exercise rehabilitation for smartphone addiction. Journal of exercise rehabilitation, 9(6), 500 .

5. Waters, K. (2015). Smartphone Medical Applications: Technology Acceptance and Usage by Medical Students' in Irish Universities.

6. Bert, F., Giacometti, M., Gualano, M. R., \& Siliquini, R. (2014). Smartphones and health promotion: a review of the evidence. Journal of medical systems, 38(1), 9995.
7. Kuss, D. J., \& Griffiths, M. D. (2011). Online social networking and addiction-a review of the psychological literature. International journal of environmental research and public health, 8(9), 3528-3552.

8. Davey S, D. A. (2014). Assessment of smartphone addiction in Indian adolescents: a mixed method study by systematic-review and meta-analysis approach. International journal of preventive medicine, 5(12): 1500.

9. Al-Khlaiwi T, M. S. (2004). Association of mobile phone radiation with fatigue, headache, dizziness, tension and sleep disturbance in Saudi population. Saudi medical journal, 25:732-6. .

10. Khan, M. (2008). Adverse effects of excessive mobile phone use. International journal of occupational medicine and environmental health, 21(4):289-93.

11. Flanagan, J. (2013, [Last updated on 2013 Oct 22.). Smart phone 'addicts' do not need rehab. Retrieved from http://www kernelmag com/features/report/6240/smart-phone-addicts-donot-need-rehab

12. Brauser, D.E. (2013). Smartphone'Addiction'May Affect Adolescent Development. The American Psychiatric Association's 2013 Annual meeting.

13. Jin S, P. M. (2019). Sleep Quality and Its Association with the Dietary Behavior and Lifestyle of University Students in Cheongju. Korean Journal of Community Nutrition, 24(5):395- 407.

14. Alosaimi, F. D., Alghamdi, A. H., Aladwani, B. S., Kazim, S. N., \& Almufleh, A. S. (2016). Workrelated stress and stress-coping strategies in residents and administrative employees working in a tertiary care hospital in KSA. Journal of Taibah University Medical Sciences, 11(1), 32-40.

15. Lim, S. H., Kim, M. H., \& Choi, M. K. (2016). Dietary life status according to smart device use of university students in Korea. The Korean Journal of Food And Nutrition, 29(3), 363-370.

16. Kim, H., \& Pae, M. (2017). Lifestyle, dietary behavior and snack preference of upper-grade elementary school students in Cheongju according to the usage time of smartphones. Korean Journal of Community Nutrition, 22(1), 40-52.

17. Al-Barashdi, H. S., Bouazza, A., \& Jabur, N. H. (2015). Smartphone addiction among university undergraduates: a literature review. Journal of Scientific Research and Reports, 210-225.

18. Khan, A. A., Khalid, A., \& Iqbal, R. (2019). Revealing the Relationship between Smartphone Addiction and Academic Performance of Students: Evidences from Higher Educational Institutes of Pakistan. Pakistan Administrative Review, 3(2), 74-83.

19. Subramani Parasuraman, A. T. S., Yee, S. W. K., Chuon, B. L. C., \& Ren, L. Y. (2017). Smartphone 
usage and increased risk of mobile phone addiction: A concurrent study. International journal of pharmaceutical investigation, 7(3), 125.

20. Kwon M, L. J. (2013). Development and validation of a smartphone addiction scale (SAS). PloS one. Feb 27;8(2):e56936.

21. Cha, S. S., \& Seo, B. K. (2018). Smartphone use and smartphone addiction in middle school students in Korea: Prevalence, social networking service, and game use. Health psychology open, 5(1), 2055102918755046.

22. Kim, I. K., Park, S. W., \& Choi, H. M. (2017). The relationship among smartphone addiction, communication ability, loneliness and interpersonal relationship for university students. Journal of the Korea AcademiaIndustrial cooperation Society, 18(1), 637-648.

23. Kim, S. E., Kim, J. W., \& Jee, Y. S. (2015). Relationship between smartphone addiction and physical activity in Chinese international students in Korea. Journal of behavioral addictions, 4(3), 200-205.

24. Kim, E. J., \& Kim, S. Y. (2015). Correlation between smartphone addiction and eating behaviors of elementary school students in Ansan area. Journal of the Korean Society of Food Science and Nutrition, 44(7), 1007-1015.

25. Mazhar, M. (2017). Level of Anxiety, Stress and Depression among the Students with and without Smartphone Addiction (Doctoral dissertation).

26. Matar Boumosleh, J., \& Jaalouk, D. (2017). Depression, anxiety, and smartphone addiction in university students-A cross sectional study. PloS one, 12(8), e0182239.
27. Park, K. (2017). Dietary and lifestyle habits and dietary behaviors according to level of smartphone addiction in university students in Kyungnam Province. Journal of the Korean Dietetic Association, 23(4), 408-430.

28. Kim, K. M., Lee, I., Kim, J. W., \& Choi, J. W. (2020). Dietary patterns and smartphone use in adolescents: A large-sample, cross-sectional study.

29. Han, S. H., Park, S. H., Lee, E. Y., \& Chang, K. J. (2017). Dietary attitudes, dietary behaviors, and smartphone usage-related dietary habits according to risk level of smartphone overdependence of elementary school students in the Siheung and Ansan areas. Journal of the Korean Society of Food Culture, 32(5), 437-445.

30. Wang, P. Y., Chen, K. L., Yang, S. Y., \& Lin, P. H. (2019). Relationship of sleep quality, smartphone dependence, and health-related behaviors in female junior college students. PloS one, 14(4), e0214769.

31. Demir, Y. P., \& Sumer, M. M. (2019). Effects of smartphone overuse on headache, sleep and quality of life in migraine patients. Neurosciences (Riyadh), 24(2), 115-21.

32. Randler, C, W. L. (2016). Smartphone addiction proneness in relation to sleep and morningnesseveningness in German adolescents. Journal of behavioral addictions, Sep;5(3):465-73.

33. Lepp A. B. J. (2013). The relationship between cell phone use, physical and sedentary activity, and cardiorespiratory fitness in a sample of US college students. International Journal of Behavioral Nutrition and Physical Activity., Dec $1 ; 10(1): 79$. 